\title{
The Exploration of the Content of CFRB in Composite Strengthening Material
}

\author{
Shao-huai Liao \\ School of Civil Engineering Wu Han University, \\ School of Civil Engineering \& Mechanics \\ Hua Zhong University of Science \& Technology \\ Wu Han, China. lshxhy@126.com
}

\author{
Yi-yan Lu \\ School of Civil Engineering \\ Wu Han University \\ Wu Han, China \\ yylu901@163.com
}

\begin{abstract}
The composite material of Carbon Fiber and steel plate is a new strengthening material. CFRB and steel plate can be seen as a kind of composite material, the force performance changes with the result of the content. The minimum content of CFRB in different CFRB and different steel plate rehabilitation is explored.The maximum content of CFRB in different CFRB and different steel plate rehabilitation is discussed. The appropriate content of CFRB in different CFRB and different steel plate is also studied. The studied result can be as a reference for engineering applications.
\end{abstract}

Keywords-CFRB and steel plate; composite rehabilitation; appropriate CFRB content

\section{INTRODUCTION}

The Carbon Fiber Reinforced Plastic or steel plate strengthening concrete components has the insuffici-ency in improving the the structures' mechanical per-formance, the two composite rehabilitation actually has the complementarity. In CFRB and steel plate co-mposite rehabilitation, CFRB and steel plate can be seen as a kind of composite material, the force perfor-mance changes with the result of the content. Test[1-6] indicates that the composite reinforcing failure pa-ttern performs as the carbon fiber cloth parts of tensi-le failure and parts of peeling off. When steel dos-age remains unchanged, the yield strength and ultimate strength of the composite material increase with the CFRB content. However, the deformation capacity of the composite material decreased (The strain of car-bon fiber cloth reduce when destroyed). Seismic str-engthening, needs materials in a higher strength, also needs to have enough deformation performance. Therefore, it is necessary to explore the appropriate content of CFRB.

\section{THE EXPLORATION OF THE MINIMUM CONTENT OF CFRB IN COMPOSITE REINFORCEMENT}

For common steel plate of Q235 and Q345, the material plasticity is good, but strength is low. We can paste CFRB to improve its strength. So the content of CFRB should not be too little in CFRB and steel composite reinforcement. On one hand, when carbon fiber cloth content is low, its failure pattern for carbon fiber cloth tensile off and quit working. On the other hand, when steel dosage remains unchanged and the content of CFRB is low, the increasing of the strength of the composite materials is limited, losing the meaning that composite reinforcement can reduce the steel plate thickness and layers. Use of composite steel reinforced concrete beam, composite materials is equivalent to the effect of steel bar. When the con-tent of carbon fiber cloth in composite materials is low, we can approximate the composite material as the steel to treat. According to

《Code for seismic de-sign of buildings(GB 50011-2010)》

[7], the ultima-te strength and the ratio of yield strength should not be less than 1.25, which can find out in composite material of carbon fiber cloth minimum content.

Composite material yield strength $N_{y}$ and ultimate strength $N_{u}$ calculation formula is:

$$
\begin{aligned}
& N_{y}=f_{b y} A_{b}+\varepsilon_{b y} E_{c f} A_{c f e} \\
& N_{u}=f_{b y} A_{b}+E_{c f} \varepsilon_{c f u, s} A_{c f} \\
& A_{c f e}=k_{m f} A_{c f}=k_{m f} n_{c f} b_{c f} t_{c f} \\
& k_{m f}=1.16-\frac{n_{c f} E_{c f} t_{c f}}{308000} \leq 0.9
\end{aligned}
$$

In formula, $A_{b}$ is for the area of steel plate, $\mathrm{mm}^{2} ; A_{c f e}$ is for the effective area of carbon fiber cloth, $\mathrm{mm}^{2} ; A_{c f}$ is for the real distribution area of carbon fiber cloth, $\mathrm{mm}^{2} ; f_{b y}$ is for the yield strength of steel plate, $N / \mathrm{mm}^{2} ; E_{b}$ is for the elastic modulus of steel plate, $N / \mathrm{mm}^{2} ; E_{c f}$ is for the elastic modulus of carbon fiber cloth, $N / \mathrm{mm}^{2} ; n_{c f}$ is for the paste layer of carbon fiber cloth; $\varepsilon_{c f u, s}$ is for the design value of ultimate tensile strain of carbon fiber cloth, for important member is 0.007 , for 
General member is $0.01 ; k_{m f}$ is for the utilization degree reduction coefficient of carbon fiber cloth[8].

With the conditions of the ultimate strength and yield strength of the ratio is 1.25 ,

$$
N_{u} \geq 1.25 N_{y}
$$

Substitute (5) with (1) and (2), we conclude:

$$
\frac{A_{c f}}{A_{b}} \geq \frac{0.25 f_{b y}}{k_{m f} E_{c f}\left(\varepsilon_{c f u, s}-1.25 \varepsilon_{b y}\right)}
$$

For Q235 steel plate, $\mathrm{E}=206000 \mathrm{MPa}, \quad f_{\text {by }}=215 \mathrm{MPa}$, so $\varepsilon_{\text {by }}=0.00104$; For composite reinforce-ment, composite materials of carbon fiber cloth in general not more than two layer. According to (4), we can solve $k_{m f}=0.9$. When reinforce important member, $\varepsilon_{c f s}=0.01$. When reinforce general member, $\varepsilon_{c f s}=0.007$. High strength in class I of CFRP, $E_{c f}=2.3 \times 10^{5} \mathrm{MPa}$; High strength in class II of CFRP, $E_{c f}=2.0 \times 10^{5} \mathrm{MPa}$. Thus, we can find out the minimum value in composite reinforcement of the ratio of CFRB area and steel plate area. See Table 1.

TABLE 1 THE MINIMUM VALUE OF THE RATIO OF CFRB AREA AND Q235 STEEL PLATE AREA

\begin{tabular}{|l|l|l|}
\hline $\begin{array}{l}\text { Importance of the } \\
\text { member }\end{array}$ & High strength & High strength \\
\hline$\frac{A_{c f}}{A_{b}}$ & in class I & in class II \\
\hline Important member & $4.56 \%$ & $5.24 \%$ \\
\hline General member & $2.98 \%$ & $3.43 \%$ \\
\hline
\end{tabular}

\section{For}

Q345

steel

plate, $\mathrm{E}=206000 \mathrm{MPa}, f_{\text {by }}=315 \mathrm{MPa}$, so $\varepsilon_{b y}=0.00153$; For composite rein-forcement, composite materials of carbon fiber cloth in general not more than two layer. According to (4), we can solve $k_{m f}=0.9$. When reinforce important member, $\varepsilon_{c f s}=0.01$. When reinforce general member, $\varepsilon_{c f s}=0.007$. High strength in class I of CFRP, $E_{c f}=2.3 \times 10^{5} \mathrm{MPa}$, High strength in class II of CFRP, $E_{c f}=2.0 \times 10^{5} \mathrm{MPa}$. Thus, we can find out the minimum value in composite reinforcement of the ratio of CFRB area and steel plate area. See Table 2.
TABLE 2 THE MINIMUM VALUE OF THE RATIO OF CFRB AREA AND Q345 STEEL PLATE AREA

\begin{tabular}{|l|l|l|}
\hline $\begin{array}{l}\text { Importance of the } \\
\text { member }\end{array}$ & High trength & High strength \\
$\frac{A_{c f}}{A_{b}}$ & in class I & in class II \\
Strength grade & & \\
\hline Important member & $7.48 \%$ & $8.60 \%$ \\
\hline General member & $4.70 \%$ & $5.14 \%$ \\
\hline
\end{tabular}

\section{THE EXPLORATION OF THE MAXIMUM CONTENT OF} CFRB IN COMPOSITE REINFORCEMENT

For reinforcing steel plate commonly used, design strength is low when the plate yield, but the ultimate strength is high when steel plate tensile off. For example, the design strength of Q235 $f_{y}=215 \mathrm{~N} / \mathrm{m}^{2}$, the tensile ultimate strength $\sigma_{b u}=370 \sim 500 \mathrm{~N} / \mathrm{m}^{2}$, the ratio of $f_{y}$ and $\sigma_{b u}$ is $f_{y} / \sigma_{b u}=0.58 \sim 0.43$. The design strength of Q345 $f_{y}=315 N / m^{2}$, the tensile ultimate strength $\sigma_{b u}=470 \sim 630 \mathrm{~N} / \mathrm{m}^{2}$, the ratio of $f_{y}$ and $\sigma_{b u}$ is $f_{y} / \sigma_{b u}=0.67 \sim 0.5{ }^{[9]}$ Due to the huge amount of steel plastic deformation, it makes the ultimate strength can not be fully used, only playing as a safety stock. However, CFRP materials high strength supplement steel plate yield strength shortage, but with carbon fiber cloth content increased, the strength of the composite materials increase more, but its plastic reduce. In order to guarantee composite materials have enough strength and ductility, we can assume that when composite materials strength does not exceed the limit of steel plate tensile strength, even carbon fiber does not destroy, but steel is still not snap, it still has a certain degree of safety. The composite material has experienced large plastic deformation. According to the request to be in composite material of carbon fiber cloth content of maximum.

Assume composite material of strong flexor ratio is $\eta=f_{y} / \sigma_{b u}$, the steel plate tensile ultimate strength can calculate with the following computation.

$$
N_{b u}=\sigma_{b u} A_{b}=\eta f_{b y} A_{b}
$$

Made of composite material of ultimate strength not greater than the limit of steel plate tensile strength conditions,

$$
N_{u} \leq N_{b u}=\eta f_{b y} A_{b}
$$


Substitute (5) with (7) and (8),

$$
\frac{A_{c f}}{A_{b}} \geq \frac{\left(\frac{1}{\eta}-1\right) f_{b y}}{k_{m f} E_{c f}}
$$

$\begin{array}{crrrrr}\text { For } & \text { Q235 } & \text { steel } & \text { plate, } \\ \mathrm{E}=206000 & \mathrm{MPa} & f_{\text {by }} & =215 & \mathrm{MPa} & \text {, take }\end{array}$ $\eta=(0.58 \sim 0.43)_{\max }=0.58$; For composite reinforcement, composite materials of car-bon fiber cloth in general not more than two layer. According to (4), we can solve $k_{m f}=0.9$. When reinf-orce important member, $\varepsilon_{c f s}=0.01$. When reinforce general member, $\varepsilon_{c f s}=0.007$. High strength in class I of CFRP $E_{c f}=2.3 \times 10^{5} \mathrm{MPa}$, High strength in class II of CFRP $E_{c f}=2.0 \times 10^{5} \mathrm{MPa}$. Thus, according to (9), we can find out the maximum value in composite reinforcement of the ratio of CFRB area and steel plate area. See Table 3.

\section{TABLE 3 THE MAXIMUM VALUE OF THE RATIO OF CFRB AREA AND Q235 STEEL PLATE AREA}

\begin{tabular}{|l|l|l|}
\hline $\begin{array}{l}\text { Importance of } \\
\text { the member }\end{array}$ & $\begin{array}{l}\text { High trength } \\
\text { in class I }\end{array}$ & $\begin{array}{l}\text { High strength } \\
\text { in class II }\end{array}$ \\
Strength grade & $10.74 \%$ & $12.36 \%$ \\
\hline $\begin{array}{l}\text { Important } \\
\text { member }\end{array}$ & $7.52 \%$ & $8.65 \%$ \\
\hline General member & & \\
\hline
\end{tabular}

$\begin{array}{crrrrr}\text { For } & \text { Q345 } & \text { steel } & \text { plate, } \\ \mathrm{E}=206000 & M P a & , \quad f_{b y}=315 \quad M P a & \text {, take }\end{array}$
$\eta=(0.67 \sim 0.5)_{\max }=0.67$; For composite reinforcement, composite materials of car-bon fiber cloth in general not more than two layer. According to (4), we can solve $k_{m f}=0.9$. When reinf-orce important member, $\varepsilon_{c f s}=0.01$. When reinforce general member, $\varepsilon_{c f s}=0.007$. High strength in class I of CFRP $E_{c f}=2.3 \times 10^{5} \mathrm{MPa}$, High strength in class II of CFRP $E_{c f}=2.0 \times 10^{5} \mathrm{MPa}$. Thus, ac-cording to (9), we can find out the maximum value in composite reinforcement of the ratio of CFRB area and steel plate area. See Table 4.
TABLE 4 THE MAXIMUM VALUE OF THE RATIO OF CFRB AREA AND Q345 STEEL PLATE AREA

\begin{tabular}{|l|l|l|}
\hline $\begin{array}{l}\text { Importance of the } \\
\text { member }\end{array}$ & $\begin{array}{l}\text { High trength } \\
\text { in class I } \\
\frac{A_{c f}}{A_{b}}\end{array}$ & $\begin{array}{l}\text { High strength } \\
\text { in class II }\end{array}$ \\
Strength grade & $10.71 \%$ & $12.31 \%$ \\
\hline Important member & $7.50 \%$ & $8.20 \%$ \\
\hline General member & & \\
\hline
\end{tabular}

According to table 3 and table 4, for Q235 and Q345 steel plate, CFRB in composite materials with steel plate material area ratio maximum basic close, we can take Q235 steel value.

\section{THE EXPLORATION OF THE APPROPRIATE CONTENT OF CFRB IN COMPOSITE REINFORCEMENT}

We can assume that carbon fiber cloth in composite materials is the reinforcement to steel plate. According to the current strengthening standards, its strength improving should not be more than $40 \%$ of the strength of the steel plate, so we can find out carbon fiber cloth appropriate content in composite material.

Steel plate yield strength can calculate like this;

$$
N_{b u}=f_{b y} A_{b}
$$

Made of composite material the ultimate tensile strength of steel plate is equal to the ultimate tensile strength of 1.4 times, we conclude:

$$
N_{u}=1.4 f_{b y} A_{b}
$$

Substitute (5) with (10) and (11):

$$
\frac{A_{c f}}{A_{b}} \geq \frac{0.4 f_{b y}}{k_{m f} E_{c f}}
$$

For Q235 steel plate, E=206000 MPa ,

$f_{\text {by }}=215 \mathrm{MPa}$;For composite reinforcement, composite materials of carbon fiber cloth in general not more than two layer. According to (4), we can solve $k_{m f}=0.9$. When reinforce important member, $\varepsilon_{c f s}=0.01$. When reinforce general member, $\varepsilon_{c f s}=0.007$. High strength in class I of CFRP $E_{c f}=2.3 \times 10^{5} \mathrm{MPa}$, High strength in class II of CFRP $E_{c f}=2.0 \times 10^{5} \mathrm{MPa}$. Thus, according to (9), we can find out the appropriate value in composite rein-forcement of the ratio of CFRB area and steel plate area. See Table 5. 
TABLE 5 THE APPROPRIATE VALUE OF THE RATIO OF CFRB AREA AND Q235 STEEL PLATE AREA

\begin{tabular}{|c|c|c|}
\hline $\begin{array}{c}\text { Importance of } \\
\text { the member } \\
\frac{A_{c f}}{A_{b}}\end{array}$ & $\begin{array}{c}\text { High } \\
\text { strength in } \\
\text { class I } \\
\text { Strength grade }\end{array}$ & $\begin{array}{c}\text { High strength } \\
\text { in class II }\end{array}$ \\
\hline $\begin{array}{c}\text { Important } \\
\text { member }\end{array}$ & $5.94 \%$ & $6.83 \%$ \\
\hline $\begin{array}{c}\text { General member } \\
\text { inger }\end{array}$ & $4.15 \%$ & $4.78 \%$ \\
\hline
\end{tabular}

TABLE 6 THE APPROPRIATE VALUE OF THE RATIO OF CFRB AREA AND Q345 STEEL PLATE AREA

\begin{tabular}{|l|l|l|}
\hline $\begin{array}{l}\text { Importance of } \\
\text { the member }\end{array}$ & $\begin{array}{l}\text { High strength } \\
\text { in class I }\end{array}$ & $\begin{array}{l}\text { High strength in } \\
\text { class II }\end{array}$ \\
Strength grade & $A_{b}$ & $10.00 \%$ \\
\hline Important member & $8.70 \%$ & $7.00 \%$ \\
\hline General member & $6.09 \%$ & \\
\hline
\end{tabular}

For Q345 steel plate, E=206000 $\mathrm{MPa}, f_{b y}=315 \mathrm{MPa}$; For composite reinforcement, com-posite materials of carbon fiber cloth in general not more than two layer. According to (4), we can solve $k_{m f}=0.9$. When reinforce important member, $\varepsilon_{c f s}=0.01$. When reinforce general member, $\varepsilon_{c f s}=0.007$. High strength in class I of
CFRP $E_{c f}=2.3 \times 10^{5} \mathrm{MPa}$, High strength in class II of $\mathrm{CFRP}_{E_{c f}}=2.0 \times 10^{5} \mathrm{MPa}$. Thus, according to (9), we can find out the appropriate value in composite reinforcement of the ratio of CFRB area and steel plate area. See Table 6.

\section{CONCLUSION}

According to the importance of the member, for different CFRB and different steel plate, the minimum value of the ratio of CFRB area to steel plate area and the maximum value of the ratio of CFRB area to steel plate area are deduced. The appr-opriate value of the ratio of CFRB area to steel plate area is also deduced . The studied result can be as a reference for engineering applications.

\section{REFERENCES}

[1] LU YE-YAN,ZHANG HAO-JUN,LIU SU-LI. Calculation of Tensile Strength of Steel Plate Bonded by Carbon Fiber Reinfor-ced Polymer[J].Journal of the Chian Railway Society , 2007, 28(5) :59-64.

[2] LIAO SHAO-HUAI,LU YI-YAN,CHENG DAO-FAN.Test on Seismic Behaviors of Reinforced Concrete Beams Composite Rehabilitation with Bonded Carbon Fiber Reinforced Polymer and Steel Plate[J].Journal of Civil Architectural and Environmental Engineering , 2010, 32(6) :14-21.

[3] LIU FEI. Application of Adhesive Steel Stabilization Technology in Architectural[J].Shanxi Architecture, 2005, 28(11):115-116.

[4] RABIONVITCH O,FROSTIG Y. Experiments and Analytical comparison of RC beams strengthened with CFRP composites[J]. Composites part B,December 1,2003, 34(8):663-677.

[5] AYMAN S KERNEL,ALAA E ELWI,ROGER J J CHENG. Experimental study on the behavior of carbon fiber reinforced polymer sheets bonded to concrete[J]. Canadian Journal of Civil Engineering.2006,33(11):47-66.

[6] TASTANI S P, PANTAZOPOULOU S J. Detailing pro-cedures for seismic rehabilitation of reinforced concrete members with fiber reinforced polymers[J]. Engineering Structures, Febru-ary 2008, 30(2): 450-461

[7] GB 50011-2010 Code for seismic design of buildings[s]. Beijing: China Building Industry Press ,2010.

[8] GB 50367-2006 Design Code for strengthening concrete structure[S] . Beijing: China Building Industry Press ,2006.

[9] SHENG RONG-FA,Study of the Ratio of Yield Strengthen and Tensile Strengthen of Hot -Rolled Strip[J]. Iron and Steel . 37(suppl.):535-537. 